\title{
Marx's Theory of Economic Crisis Needs to Keep Pace with the Times
}

\author{
SuiSheng Zhao \\ Xijing University, Department of Ideological and Political Education, No1 Xijing Road, Chang'an, Xi'an, \\ Shaanxi 710123 \\ zhaosuisheng@126.com
}

\section{Keywords: Marx; Political economy; Surplus value theory; Economic crisis theory}

\begin{abstract}
Marx's economic crisis theory is an important part of the surplus value theory. The economic crisis theory is the logical premise and direct basis of "two necessities". The emerging new situation in the development of contemporary capitalism and socialism has questioned and challenged Marx's economic crisis theory. The correct understanding of the new changes in contemporary capitalism and socialism and the improvement of Marx's economic crisis theory are major issues lying in theory research.
\end{abstract}

\section{Marx's Economic Crisis Theory is Facing New Problems in the Development of Times}

Economic crisis theory constitutes the important content of Marx's surplus value theory. The surplus value theory by using the theory and method of historical materialism of Marx, dissecting the capitalist mode of production and internal contradictions of the development process, reached an important conclusion: the economic crisis is the inevitable outcome of the capitalist system, and it will eventually lead to the demise of the capitalist system. The economic crisis theory is the logical premise as well as important and direct basis of two inevitable conclusions, through the economic crisis theory the doctrine of surplus value reveals and clarifies the inevitability of socialism instead of capitalism.

Today, more than 100 years after Marx's death, many new changes, new situations and new problems have emerged in the development of the times. The theory of the economic crisis of Marx is facing the challenge of how to keep pace with the times.

First of all, after the Second World War, the capitalist countries have changed a lot in the aspects of economy and politics. Firstly, the ownership of the means of production has undergone major changes, it has become a mainstream for the legal person's property rights to replace the natural person property rights, and socialization of capital occupation has greatly improved. Secondly, there have been important changes in labor relations and distribution relations. A great contradiction between labor and capital has been eased. Thirdly, social class and class structure have changed, white-collar and middle classes expand, social stability has been enhanced. Last but not least, capitalist democratic system has undergone continuously improvement, providing a more adequate channel for the interests of all sectors of society to express and defend the interests of the rights.

Secondly, after the Second World War, the forms of economic crisis of capitalist countries have changed greatly. The capitalist countries strengthen the intervention in the economy, the economic crisis during the recession and destructive greatly reduced; the economic crisis between four different phases than in the past; improve the social security system, the economic crisis on the intensification of social contradictions is greatly reduced. These changes occurred in the era of capitalist countries, and Marx had to see the situation is different, the economic crisis and not the capitalism forced to destruction of the dead, the developed capitalist countries still has strong vitality.

Thirdly, the development of socialist economy raises new questions. The founders of Marx have predicted that the future of socialism will completely eliminate the economic crisis. Once the society has the means of production, the production of goods will be eliminated, and the rule of the producer will be eliminated. The anarchy of social production will be replaced by a planned, conscious organization." ${ }^{[1]}$ (P.633) but in our country to explore the establishment of a socialist market economic system in the process of more than 
twenty years, we call it "weak market," the emergence of a number of overproduction crisis. The academic circles in our country for more than thirty years of socialist economic crisis research in the following viewpoint has basically reached a consensus: first, the economic crisis is not a peculiar economic category of capitalist society; second, the economic crisis is the inevitable outcome of market economy, social performance of the market is the inevitable cyclical fluctuations of large production conditions; third the socialist countries, a surplus of the economic crisis, is a reflection of the objective law of market economy; fourthly, socialist economic crisis and capitalist economic crisis in a certain area don't in the cause, but has many common features.

\section{The Challenge of Marx's Economic Crisis Theory}

First of the Questions and Challenges: The economic crisis is not the product of the capitalist system? Marx believes that the possibility of economic crisis in the simple commodity economy has already existed, but only in the capitalist social production conditions, the economic crisis is inevitable. In the future socialist commodity economy will gradually disappear, the currency will disappear, the economic crisis will no longer exist. The conclusion is that the economic crisis is a peculiar phenomenon in capitalist society, and it is the product of capitalist system. However, the emergence of the socialist economic crisis is undoubtedly questioned and challenged this conclusion. Most of the scholars in academic circles of our country is that the economic crisis is not a characteristic of capitalist society economic category, but a variety of social common economic category; ${ }^{[2]}$ socialist commodity economy and socialized production, determines the inevitable cyclical economic fluctuations. ${ }^{[3]}$ although the reason people have to the socialist economic crisis had a different explanation, but a sharp question mentioned before the people: the economic crisis in the end is the capitalist system is a product of socialized production and market economy?

The Second Question and Challenge: Is the contradiction between the internal organization of production and the anarchy of the whole society? Marx thinks that one of the basic contradictions of capitalism is that the internal production of individual enterprises is organized, and the whole social production is anarchy. But the former Soviet Union, and other socialist countries Chinese planned economy practice has proved that the government cannot production plan reflect the market supply and demand, can also lead to social production "anarchy". In our country under the condition of socialist market economy, the non-public enterprises, there exists a contradiction between social production and the production of non-public ownership, public ownership enterprises, there is a contradiction between social production and the production data share between local enterprises. Public owned enterprises in the face of market autonomy, but also will lead to the imbalance of the whole social resource allocation, excess capacity, will also form a whole social production anarchy".

Question and Challenge Three: Whether social production plan can avoid excess crisis? Marx believes that the future of socialism means the public possession of the means of production, and the social production is completely under the plan, so as to overcome the anarchy of production and avoid the occurrence of economic crisis. "Because the society will deprive private capitalists of all productive forces and means of exchange control, as well as their products exchange and distribution rights, because the society will be in accordance with the actual resources and according to the needs of society as a whole plan to manage all of this, so with the current big industry management system linked to all the harmful consequences first of all, will be eliminated. The crisis will end." ${ }^{[4]}$ but the practice of the planned economy of the socialist countries has proved that the planned economy is not more rational than the market to achieve economic development. Due to the market supply-demand relationship is very complex and changeable, from government mandatory planning and the market is difficult to avoid, so often there such a contradiction: on the one hand, a large number of production and living materials to meet the needs of society, on the other hand, some products structural surplus. But this excess production does not take the economic crisis under the planned economy system the way to express it, the reason is in the enterprise under the planned economy system and are swept by the government, will not feel the pressure of surplus. 
Question and Challenge Four: The law of surplus value is not characteristic of capitalist society rules? Marx thinks that the surplus value of production is the basic economic law of capitalist mode of production. Capitalist pursuit of surplus value insatiably avaricious nature, promote the capitalists to expand production, will inevitably lead to overproduction crisis occurred periodically. That practice, planned economy in the past "big" rigid system, causes the enterprise to completely lose the enthusiasm of production and operation, do not care about the economic benefits. The reform of China socialist market economic system, the state-owned enterprises to the market, make it become independent economic entities and corporations, the state-owned enterprises vitality once was released. The law of value is to play the role of regulating the social economy through the mechanism of interest, the enterprise will not have the business vitality without the economic benefits. China's theoretical circles still do not recognize the category of socialist surplus value, which is not necessary. Surplus value and capital, capital, stock, dividends, and other categories, but also has a dual nature and natural attributes, in different social systems and economic relations, it reflects different social relations. ${ }^{[5]}$ the public owned enterprises can survive and develop only in the pursuit of economic benefits, in order to better serve the purpose of socialist production. In addition, there are a large number of non-public enterprises in the primary stage of socialism, and their business purpose is directly subordinate to the law of surplus value. Since the law of surplus value (in public ownership enterprises or profit law) not only exist in capitalism, socialism also exist and play a role in it, the law of surplus value is defined as the special rules of the capitalist mode of production is worth rethinking.

Question and Challenge Five: The production of anarchy is a drawback is not a capitalist economy system? Marx believe that the origin of the capitalist economic crisis lies in the means of production the capitalist private ownership, each enterprise is subject to the law of surplus value and independent investment activities, so that the whole social production in a state of anarchy. Only the public possession of the means of production, the whole society to implement planned production, in order to avoid the economic crisis. "The means of production by social possession, not only to eliminate the production of existing artificial barriers, but also eliminate the waste and destruction of productive forces and tangible products, the waste and destruction in the current production is unable to get rid of the partner, and reached the peak in the period of crisis." ${ }^{[1](.59-60)}$ the so-called capitalist production anarchy, in essence, is the capitalist countries to the value of this "invisible hand" as the basic means of market regulation. We used to be blind to the role of the "visible hand" of the government plan and thought it was the embodiment of the superiority of the socialist system. However, the economic practice of the socialist countries shows that the invisible hand is more effective and sensitive than the "visible hand" in the allocation of resources and market regulation mechanism. The third Plenary Session of the 18th CPC Central Committee again stressed: the core issue of economic reform is to deal with the relationship between the government and the market, so that the market plays a decisive role in the allocation of resources. Since the market is the most efficient allocation of resources, so we present through deepening reform to pursue this production of "anarchy", the traditional concept of abuse of it as a criticism of capitalism is worth rethinking.

Question and Challenge Six: the production of relative surplus is not capitalist phenomenon? Marx believes that the pursuit of surplus value of the nature of capitalism, so that the production of unlimited expansion of the trend, while the working people have the ability to pay the demand is relatively narrow, it will inevitably lead to the occurrence of the relative excess crisis. But we can see that the rapid development of modern science and technology is creating more and more powerful productive forces. Not only the capitalist countries, China's reform and opening up more than thirty years, so that we quickly bid farewell to the shortage of the economy, but also began to face the excess worry". China's overcapacity has spread to most of the trade and industry, but on the other hand, according to the world bank standards, China also has more than 200 million of the population living below the poverty line, their basic needs can not be met. This is China's real estate industry, is a serious backlog of vacant rooms, but at the same time, a large number of low-income families unable to purchase. It is clear that the house is not an absolute surplus with other products, but only a relative surplus. It can be seen that the relative surplus of production is a very complex 
social and economic problem, not only in capitalist society.

Questions and Challenges of the Seven: The economic crisis is not the root cause of capitalism is the socialist alternative? Marx, by virtue of the theory of economic crisis, demonstrates the temporary and transitional nature of capitalism. In summary, if the economic crisis is not a unique phenomenon in capitalist society, the individual enterprise production organization and the social production of anarchy conflict also exists in socialist society, planned production can not avoid excess crisis, drawbacks of production "anarchy" is not a capitalist mode of production, the production of relative surplus is not the capitalist phenomenon -- if this series of main points of Marx's economic crisis theory need to rethink it will involve a deeper and more acute problem, that is the historical inevitability of socialism will replace capitalism is how to explain? Human history proves the rule of social basic contradiction of historical materialism reveals the truth is able to withstand heavy battering according to historical materialism theory, we have reason to believe that capitalism will be replaced by a more advanced form of society, so far the history proved that a system will not exist forever. Capitalism and history as any form of society, the development of productive forces to accommodate production relations, must change the relations of production, new production mode and social system for the development of productive forces. The problem is that the historical transition of capitalism needs to be more reasonable and sufficient. ${ }^{[6]}$

\section{Conclusion: Marx's Economic Crisis Theory Needs to Keep Pace with the Times}

Marx's economic crisis theory is faced with challenges and challenges, does not mean that the theory of the crisis facing the Marx. Marx doctrine provides us with a scientific world outlook and methodology for observing and understanding the nature of the society and its history, and its basic standpoint, viewpoint and method will not be out of date, and the conclusion of "Two Necessities" is not out of date. However, some of the views and conclusions of Marx doctrine may need to be revised and renewed with the development of society. As Deng Xiaoping pointed out: "we must not ask Marx to solve the problems of the past hundred years, hundreds of years after his death....... The real Marx and the Lenin must be based on the current situation, to understand, inherit and develop the theory of the Marxism of the Chinese Communist Party of the Republic of China, which is based on the current situation of the people of the Republic of China and the world. In this way, the." ${ }^{7]}$ how to further emancipate the mind, get rid of the shackles of socialism and capitalism "rigid thinking, put in the original social system belongs to the common law of market economy on the label torn off, objective understanding of the essence and characteristics of market economy; how to correctly understand the new changes of contemporary capitalism and socialism happen; how to revise and improve the theory of Marx's economic crisis. We promote a more profound understanding and grasp the development law of socialism and capitalism, is a major issue in front of Marx theory.

\section{Reference}

[1] Marx Engels Selected Works (third volumes) M. Beijing: People's Publishing House.1995.

[2] Li Yunfu and Zhu Xiao: A Preliminary Study of The Socialist Economic Crisis And Economic Cycle [J]. Academic Journal 1989.4.

[3] Zhang Ruiqin: A Preliminary Study on The Theory of Socialist Economic Cycle [J]. Theoretical Study 2007.8.

[4] Marx Engels Selected Works (first volumes) M. Beijing: People's Publishing House.1995. Page 241-242.

[5] Zhao Suisheng: Reflections on The Category of Socialist Surplus Value [J]. Journal of Xi'an Aerotechnical College 2009.5.

[6] Zhao Suisheng:A Review of The Research on The Problems of Socialist Economic Crisis [J]. Journal of Xijing University 2014.4.

[7] Deng Xiaoping Selected Works (third volumes) M. Beijing: People's Publishing House.2001. Page 291. Author introduction: Suisheng Zhao, male, Han nationality, born in October 1953, of Shaanxi Province, 
Qingjian County, Master's degree,ideological Department of Xijing University professor. Main research interests: Marx's theory and ideological and political education. 